\title{
IMPACT OF SOCIAL MEDIA REVIEWS ON CINE ENTHUSIASTS WITH SPECIAL REFERENCE TO BOLLYWOOD MOVIES
}

\author{
Abdul Rahim Ahmed Munshi \\ ITM Universe, India
}

\begin{abstract}
Every now and then you come across a social media post either criticizing a movie or praising a movie. Does it really matter what either experts or a commoner has to say about his or her review of a movie? In an age where the digital word spreads faster than the speed of light, does a FB Post, a twitter tweet, a book my show review, or an $I M d b$ review impact the movie going intentions of people. This research paper aims to answer all such questions and throw light on whether social media word decides the box office fate of bollywood movies. Several tests of associations and mean difference were used in this study to see whether there was an association among demographic factors, movie preferences and factors effecting movie choice. Additionally an effort was made to check whether demographic factors have got any effect on the effectiveness of social media reviews. Results of this paper will help filmmakers understand whether positive word of mouth by common public, media firms and film critics should be monitored and considered seriously or should it be left unnoticed.
\end{abstract}

Keywords: Movie Preference, Social Media Reviews, E-Wom

Cite this Article: Abdul Rahim Ahmed Munshi, Impact of Social Media Reviews on Cine Enthusiasts with Special Reference to Bollywood Movies, Journal of Management, 6 (2), 2019, pp. 177-186.

http://www.iaeme.com/JOM/issues.asp?JType=JOM\&VType=6\&IType=2

\section{INTRODUCTION}

Wave of Social media has struck all the countries around the world and India is no different, as per estimates of one renowned market research company (Statista), the number of social media users in India have multiplied from 142.3 million to 351.4 million in 2019 and it is estimated by 2023 the number of social media users in India will increase to 447.9 million. Facebook is the most preferred social media platform where the number of users has increased from 135.6 million to 313.6 million in 2019 and is expected to increase to 444.2 million by 2023. Similarly the number of twitter users increased from 11.5 million to 34.4 million in 2019. Because of the increase in the number of social media users, this platform is being leveraged by marketers for promoting their products and services. Social media marketing has been getting a lion's share of attention and allocation in the marketing budgets. Film industry of India popularly known as 
bollywood is not immune to this phenomenon. Promotion teams of movies have been actively using social media platforms to promote their movies, the results of which have been clearly visible for a number of movies like Dangal, Chennai Express, Queen and many more movies. While the industry is busy promoting their movies on social media platforms there are other forces that are operating in the form of independent reviews of social media users as well as film critics. The decision to watch or skip a movie is influenced by a number of factors and some of the important influencers are peer input (word of mouth) and judgment of professional critics. The research problem in this study is how effective are these reviews and user generated content in the form of facebook posts, twitter tweets, IMDb reviews and book my show reviews in influencing the attitude or opinions of movie goers. In this study we also seek to analyze whether demographic factors have got any impact on the effectiveness of reviews across social media platforms. Secondly we also want to see if demographic factors have an impact on movie preferences and factors influencing movie decisions.

\section{LITERATURE REVIEW}

Individual differences have been recognized as a key to understanding the uses and effects of mass media (Kerrigan, 2010; Weaver, 1991). Additionally, investigations have been done on the relationship between mass media use and personality characteristics. Extant literature has suggested that media usage and preferences are influenced by a wide range of social, psychological and demographic variables (Kraaykamp \& Van Eijck, 2005; Nabi, Finnerty, Domschke \& Hull, 2006; Sargent, Zillmann \& Weaver, 1998).

The film industry is an amalgamation of fiction, art, business, and entertainment, culture, to which all have access and can relate to in some way or the other. Hence this industry is of prime importance to our society giving glimpses of lives people are not usually exposed to (Anderson \& Iannaco, 2010)

Common wisdom in media houses say that both men and women prefer different types of films, this has been supported by genre and content classification (Gantz \& Wenner, 1991; Tamborini, Stiff, \& Zillmann, 1987). Fischoff, Antonio, and Lewis (1998) argue that women prefer those movies whose content is women centric revolving around women issues (eg, Queen, Manikarnika, Gulaab Gang etc) or the protragonist is a female lead. On the other hand men prefer those movies which are high on action, romance and competition (Fischoff, 1994). Women also show an inclination towards sad films those that revolved around relational tragedies such as failure of romantic relationships, or death of loved ones; (Oliver et al., 2000).

Men tend to prefer those movies that tend to arouse their emotions; these include crime thrillers mysteries, and horror movies (Grabe \& Kamhawi, 2006; Janssen, Carpenter, \& Graham, 2003).

There is a dearth of literature on consumer behavior with respect to bollywood movies and immense potential to carry forward research in this niche area, however on the basis of available literature, the following hypothesis have been formulated,

H1 Movie Preferences are Demographic Specific.

$\mathrm{H} 2$ Factors Impacting Movie Preferences are Demographic Specific.

Previous studies have found differences in consumption patterns for social media between men and women (Boneva etal., 2001; Roberts et al., 2005; Song et al., 2009). Females generally use more time online for visiting websites, sending/receiving mails, and on instant messaging whereas males spend more time in gaming (Park and Lee, 2014).

Studies have also shown that males use social media for making new friends and relations than females (Mazman and Usluel, 2011). Also they argue that men use social media for 
strengthening networks and increase their social circle whereas females use the same for keeping in touch with existing friends.

Earlier research studies claim that males tend to lean towards information that confirms their own thoughts and opinions and disregard information that invalidates their hypotheses due to their natural tendency to maintain agency and self-esteem; on the other hand females are less concerned about validating their hypothesis and seek information that reduces discrepancy in opinions (Chung, J. and Monroe, 1998).

H3 Effectiveness of Social Media reviews differs across demographic groups.

\section{RESEARCH OBJECTIVES}

a. To analyze the association between demographic factors and movie preference.

b. To analyze the association between demographic factors and factors impacting movie preference.

c. To analyze whether demographic factors have an influence on effectiveness of Social Media reviews of Bollywood Movies.

\section{RESEARCH METHODOLOGY}

The research design used in this study was descriptive research with an aim to prove several hypotheses. A questionnaire was developed using likert scale as the research instrument. Data was collected from a sample of 250 respondents aggregated through non-probability convenience sampling and was analyzed using SPSS. For hypotheses testing Chi-Square tests was used to check association between demographic factors and movie preferences, Independent Sample T-Test and Anova was used to check whether demographic factors have an influence on effectiveness of social media reviews of bollywood movies.

\section{RESULTS AND DISCUSSION}

Hypothesis were tested using several tests of mean difference and the combined results are indicated in table No.1.The results supported the first hypothesis viz. Movie preferences are demographic specific. This supports literature which says gender has an influence on the genre of movies, whereby males prefer action and thriller movies, females have inclination towards romcom and comedy movies and kids prefer action and animated movies. The second hypothesis, factors impacting movie preferences was partially supported, in which age and occupation was found to have an association with factors affecting movie preferences. This was also in line with extant literature that says that people of different age groups and occupations tend to be influenced by different factors while choosing which movies to watch. These include brand image of the actor/actress, production house, and ratings by movie critics, recommendation by friends/colleagues and the like. The third hypothesis, effectiveness of social media differs across age groups were also partially supported. It was found that FB posts on movie reviews are effective in influencing the movie going intentions only among specific age groups. Same was the case with twitter reviews, IMDb movie reviews and book my show reviews. It was also found that effectiveness of book my show reviews had an effect on the movie going intentions among different occupation groups. Another important finding was that there was no difference in the effectiveness of social media among males and females. This was true for all social media platforms which included facebook and twitter as well as ticket booking platform Book my show. 
Table 1 Hypothesis and Test Results

\begin{tabular}{|c|c|c|c|}
\hline Hypothesis & Test & P-Value & Hypothesis Result \\
\hline \multicolumn{4}{|l|}{$\begin{array}{l}\text { H1 Movie Preferences are } \\
\text { Demographic Specific. }\end{array}$} \\
\hline $\begin{array}{l}\text { H1a There is an association between } \\
\text { Movie Preferences and Gender }\end{array}$ & Chi-Square & .000 & Supported \\
\hline $\begin{array}{c}\text { H1b There is an association between } \\
\text { Movie Preferences and Age }\end{array}$ & Chi-Square & .010 & Supported \\
\hline $\begin{array}{l}\text { H1c There is an association between } \\
\text { Movie Preferences and Occupation }\end{array}$ & Chi-Square & .042 & Supported \\
\hline \multicolumn{4}{|l|}{\begin{tabular}{|c|}
$\mathrm{H} 2$ Factors Impacting Move \\
Preferences are Demographic Specific.
\end{tabular}} \\
\hline $\begin{array}{c}\text { H2a There is an association between } \\
\text { Age and Factors Impacting Movie } \\
\text { Preferences }\end{array}$ & Chi-Square & .044 & Supported \\
\hline $\begin{array}{c}\mathrm{H} 2 \mathrm{~b} \text { There is an association between } \\
\text { Gender and Factors Impacting Movie } \\
\text { Preferences }\end{array}$ & Chi-Square & .408 & Not Supported \\
\hline $\begin{array}{c}\text { H2c There is an association between } \\
\text { Occupation and Factors Impacting } \\
\text { Movie Preferences }\end{array}$ & Chi-Square & .035 & Supported \\
\hline \multicolumn{4}{|l|}{$\begin{array}{c}H 3 \text { Effectiveness of Social Media } \\
\text { reviews is different across demographic } \\
\text { groups }\end{array}$} \\
\hline $\begin{array}{c}\text { H3a Effectiveness of FB Posts on } \\
\text { movie going intentions differ across age } \\
\text { groups }\end{array}$ & Anova & .007 & Supported \\
\hline $\begin{array}{l}\text { H3b Effectiveness of FB Posts on } \\
\text { movie going intentions differ across } \\
\text { gender }\end{array}$ & $\begin{array}{c}\text { Independent } \\
\text { Sample T-Test }\end{array}$ & .579 & Not Supported \\
\hline $\begin{array}{l}\text { H3c Effectiveness of FB Posts on } \\
\text { movie going intentions differ across } \\
\text { Occupation groups }\end{array}$ & Anova & .922 & Not Supported \\
\hline \begin{tabular}{|c|} 
H3d Effectiveness of Twitter reviews \\
on movie going intentions differ across \\
Age groups
\end{tabular} & Anova & .001 & Supported \\
\hline $\begin{array}{c}\text { H3e Effectiveness of Twitter reviews on } \\
\text { movie going intentions differ across } \\
\text { gender }\end{array}$ & $\begin{array}{c}\text { Independent } \\
\text { Sample T-Test }\end{array}$ & .341 & Not Supported \\
\hline \begin{tabular}{|c|}
$\begin{array}{c}\text { H3df Effectiveness of Twitter reviews } \\
\text { on movie going intentions differ across } \\
\text { Occupation groups }\end{array}$ \\
\end{tabular} & Anova & .828 & Not Supported \\
\hline $\begin{array}{l}\text { H3g Effectiveness of IMdb movie } \\
\text { reviews differ across Age groups }\end{array}$ & Anova & .003 & Supported \\
\hline $\begin{array}{l}\text { H3h Effectiveness of IMdb movie } \\
\text { reviews on movie going intentions } \\
\text { differ across gender }\end{array}$ & $\begin{array}{c}\text { Independent } \\
\text { Sample T-Test }\end{array}$ & .233 & Not Supported \\
\hline $\begin{array}{l}\text { H3i Effectiveness of IMdb movie } \\
\text { reviews on movie going intentions } \\
\text { differ across Occupation groups }\end{array}$ & Anova & .021 & Supported \\
\hline
\end{tabular}


Impact Of Social Media Reviews on Cine Enthusiasts with Special Reference to Bollywood Movies

\begin{tabular}{|c|c|c|c|}
\hline $\begin{array}{c}\text { H3j Effectiveness of Book my show } \\
\text { reviews on movie going intentions } \\
\text { differ across Age groups }\end{array}$ & Anova & .024 & Supported \\
\hline $\begin{array}{c}\text { H3k Effectiveness of Book my Show } \\
\text { reviews on movie going intentions } \\
\text { differ across Gender }\end{array}$ & $\begin{array}{c}\text { Independent } \\
\text { Sample T-Test }\end{array}$ & .260 & Not Supported \\
\hline $\begin{array}{c}\text { H31 Effectiveness of Book my Show } \\
\text { reviews on movie going intentions } \\
\text { differ across Occupation groups }\end{array}$ & Anova & Supported \\
\hline
\end{tabular}

Table 1.1 Chi-Square test values for association between Gender and Movie Preferences

Chi-Square Tests

\begin{tabular}{|c|c|c|c|}
\hline & Value & df & Asymp. Sig. (2-sided) \\
\hline Pearson Chi-Square & $58.200^{\mathrm{a}}$ & 4 & .000 \\
\hline Likelihood Ratio & 66.225 & 4 & .000 \\
\hline Linear-by-Linear Association & 26.784 & 1 & .000 \\
\hline N of Valid Cases & 200 & & \\
\hline
\end{tabular}

a. 2 cells $(20.0 \%)$ have expected count less than 5 . The minimum expected count is 1.95 .

Table 2 Chi-Square test values for association between Age and Movie Preferences

\begin{tabular}{|c|c|c|c|}
\hline \multicolumn{4}{|c|}{ Chi-Square Tests } \\
\hline & Value & df & Asymp. Sig. (2-sided) \\
\hline Pearson Chi-Square & $37.682^{\mathrm{a}}$ & 20 & .010 \\
\hline Likelihood Ratio & 39.185 & 20 & .006 \\
\hline Linear-by-Linear Association & .013 & 1 & .909 \\
\hline $\mathrm{N}$ of Valid Cases & 200 & & \\
\hline
\end{tabular}

Table 3 Chi-Square test values for association between Occupation and Movie Preferences

\begin{tabular}{|c|c|c|c|}
\hline \multicolumn{5}{|c|}{ Chi-Square Tests } \\
\hline & Value & df & Asymp. Sig. (2-sided) \\
\hline Pearson Chi-Square & $15.996^{\mathrm{a}}$ & 8 & .042 \\
\hline Likelihood Ratio & 16.991 & 8 & .030 \\
\hline Linear-by-Linear Association & .028 & 1 & .867 \\
\hline N of Valid Cases & 200 & & \\
\hline \multicolumn{2}{|c|}{ a. 3 cells (15.0\%) have expected count less than 5. The minimum expected count is .68. } \\
\hline
\end{tabular}

Table 4 Chi-Square test values for association between Age and Factors Impacting Movie Preferences

\begin{tabular}{|c|c|c|c|}
\hline \multicolumn{5}{|c|}{ Chi-Square Tests } \\
\hline & Value & df & Asymp. Sig. (2-sided) \\
\hline Pearson Chi-Square & $31.897^{\mathrm{a}}$ & 20 & .044 \\
\hline Likelihood Ratio & 35.407 & 20 & .018 \\
\hline Linear-by-Linear Association & .333 & 1 & .564 \\
\hline N of Valid Cases & 200 & \\
\hline a. 2 cells (20.0\%) have expected count less than 5. The minimum expected count is .10. \\
\hline
\end{tabular}


Table 5 Chi-Square test values for association between Gender and Factors Impacting Movie Preferences

\begin{tabular}{|c|c|c|c|}
\hline \multicolumn{5}{|c|}{ Chi-Square Tests } \\
\hline & Value & df & Asymp. Sig. (2-sided) \\
\hline Pearson Chi-Square & $3.984^{\mathrm{a}}$ & 4 & .408 \\
\hline Likelihood Ratio & 3.928 & 4 & .416 \\
\hline Linear-by-Linear Association & 2.794 & 1 & .095 \\
\hline N of Valid Cases & 200 & & \\
\hline a. 2 cells (20.0\%) have expected count less than 5. The minimum expected count is 3.90. \\
\hline
\end{tabular}

Table 6 Chi-Square test values for association between Occupation and Factors Impacting Movie Preferences

\begin{tabular}{|c|c|c|c|}
\hline \multicolumn{4}{|c|}{ Chi-Square Tests } \\
\hline & Value & df & Asymp. Sig. (2-sided) \\
\hline Pearson Chi-Square & $16.576^{\mathrm{a}}$ & 8 & .035 \\
\hline Likelihood Ratio & 18.164 & 8 & .020 \\
\hline Linear-by-Linear Association & .687 & 1 & .407 \\
\hline N of Valid Cases & 200 & & \\
\hline a. 3 cells (18.7\%) have expected count less than 5. The minimum expected count is 1.35. \\
\hline
\end{tabular}

Table 7 Anova test values for mean difference between age groups for effectiveness of FB Posts on movie going intentions

\begin{tabular}{|c|c|c|c|c|c|}
\hline \multicolumn{7}{|c|}{ ANOVA } \\
\hline & Sum posts are likely to influence my movie going intentions \\
\hline Between Groups & 12.084 & 5 & 2.417 & 3.281 & Sig. \\
\hline Within Groups & 142.911 & 194 & .737 & & .007 \\
\hline Total & 154.995 & 199 & & & \\
\hline
\end{tabular}

Table 8 Independent Sample t- test values for mean difference between gender groups for effectiveness of FB Posts on movie going intentions

\begin{tabular}{|c|c|c|c|c|}
\hline \multicolumn{5}{|c|}{ Independent Samples Test } \\
\cline { 3 - 5 } & & \multicolumn{3}{|c|}{ t-test for Equality of Means } \\
\hline \multicolumn{2}{|c|}{} & df & Sig. (2-tailed) & Mean Difference \\
\hline $\begin{array}{c}\text { FB posts are likely to } \\
\text { influence my movie going } \\
\text { intentions }\end{array}$ & Equal variances assumed & 198 & .579 & .07125 \\
\cline { 2 - 5 } & Equal variances not assumed & 166.347 & .578 & .07125 \\
\hline
\end{tabular}


Impact Of Social Media Reviews on Cine Enthusiasts with Special Reference to Bollywood Movies

Table 9 ANOVA test values for mean difference between Occupation groups for effectiveness of FB Posts on movie going intentions

\begin{tabular}{|c|c|c|c|c|c|}
\hline \multicolumn{7}{|c|}{ ANOVA } \\
\hline \multicolumn{7}{|c|}{ FB posts are likely to influence my movie going intentions } \\
\hline & Sum of Squares & df & Mean Square & F & Sig. \\
\hline Between Groups & .127 & 2 & .064 & .081 & .922 \\
\hline Within Groups & 154.868 & 197 & .786 & & \\
\hline Total & 154.995 & 199 & & & \\
\hline
\end{tabular}

Table 10 Anova test values for mean difference between age groups for effectiveness of Twitter reviews on movie going intentions

\begin{tabular}{|c|c|c|c|c|c|}
\hline \multicolumn{7}{|c|}{ ANOVA } \\
\hline \multicolumn{7}{|c|}{ Twitter posts are likely to influence my movie going intentions } \\
\hline Sum of Squares & df & Mean Square & F & Sig. \\
\hline Between Groups & 26.547 & 5 & 5.309 & 4.393 & .001 \\
\hline Within Groups & 234.473 & 194 & 1.209 & & \\
\hline Total & 261.020 & 199 & & & \\
\hline
\end{tabular}

Table 11 Independent Sample T-Test for mean difference between Genders for effectiveness of Twitter reviews on movie going intentions

\begin{tabular}{|c|c|c|c|c|}
\hline \multicolumn{5}{|c|}{ Independent Samples Test } \\
\cline { 3 - 5 } & & \multicolumn{3}{c|}{ t-test for Equality of Means } \\
\hline \multicolumn{2}{|c|}{} & df & Sig. (2-tailed) & Mean Difference \\
\hline $\begin{array}{c}\text { Twitter posts are likely to } \\
\text { influence my movie going } \\
\text { intentions }\end{array}$ & Equal variances assumed & 198 & .341 & -.15847 \\
\cline { 2 - 5 } & Equal variances not assumed & 150.602 & .353 & -.15847 \\
\hline
\end{tabular}

Table 12 Anova test values for mean difference between occupation groups for effectiveness of

Twitter reviews on movie going intentions

\begin{tabular}{|c|c|c|c|c|c|}
\hline \multicolumn{7}{|c|}{ ANOVA } \\
\hline & Twitter posts are likely to influence my movie going intentions & F & Sig. \\
\hline Sum of Squares & df & Mean Square & .189 & .828 \\
\hline Within Groups & 260.521 & 2 & .250 & & \\
\hline Total & 261.020 & 197 & 1.322 & & \\
\hline
\end{tabular}

Table 13 Anova test values for mean difference between age groups for effectiveness of IMDb reviews on movie going intentions

\begin{tabular}{|c|c|c|c|c|c|}
\hline \multicolumn{7}{|c|}{ ANOVA } \\
\hline & Sum of Squares & df & Mean Square & F & Sig. \\
\hline Between Groups & 17.899 & 5 & 3.580 & 3.669 & .003 \\
\hline Within Groups & 189.296 & 194 & .976 & & \\
\hline Total & 207.195 & 199 & & & \\
\hline
\end{tabular}


Table 14 Independent Sample T-Test for mean difference between gender groups for effectiveness of $\mathrm{IMDb}$ reviews on movie going intentions

\begin{tabular}{|c|c|c|c|c|}
\hline \multicolumn{5}{|c|}{ Independent Samples Test } \\
\cline { 3 - 5 } & & \multicolumn{3}{c|}{ t-test for Equality of Means } \\
\hline \multicolumn{2}{|c|}{} & df & Sig. (2-tailed) & Mean Difference \\
\hline $\begin{array}{c}\text { IMDB reviews are likely to } \\
\text { influence my movie going } \\
\text { intentions }\end{array}$ & Equal variances assumed & 198 & .233 & -.17675 \\
\cline { 2 - 5 } & Equal variances not assumed & 180.068 & .219 & -.17675 \\
\hline
\end{tabular}

Table 15 Anova Test values for mean difference between occupation groups for effectiveness of $\mathrm{IMDb}$ reviews on movie going intentions

\begin{tabular}{|c|c|c|c|c|c|}
\hline \multicolumn{7}{|c|}{ ANOVA } \\
\hline & Sum of Squares & df & Mean Square & F & Sig. \\
\hline Between Groups & 7.949 & 2 & 3.974 & 3.930 & .021 \\
\hline Within Groups & 199.246 & 197 & 1.011 & & \\
\hline Total & 207.195 & 199 & & & \\
\hline
\end{tabular}

Table 16 Anova test values for mean difference between age groups for effectiveness of Book my show reviews on movie going intentions

\begin{tabular}{|c|c|c|c|c|c|}
\hline \multicolumn{7}{|c|}{ ANOVA } \\
\hline & Sum of Squares & df & Mean Square & F & Sig. \\
\hline Between Groups & 9.342 & 5 & 1.868 & 2.656 & .024 \\
\hline Within Groups & 136.478 & 194 & .703 & & \\
\hline Total & 145.820 & 199 & & & \\
\hline
\end{tabular}

Table 17 Independent Sample t-test values for mean difference between gender groups for effectiveness of Book my show reviews on movie going intentions

\begin{tabular}{|c|c|c|c|c|}
\hline \multicolumn{5}{|c|}{ Independent Samples Test } \\
\cline { 3 - 5 } & & \multicolumn{3}{c|}{ t-test for Equality of Means } \\
\hline \multicolumn{2}{|c|}{} & df & Sig. (2-tailed) & Mean Difference \\
\hline $\begin{array}{c}\text { Book my show reviews are } \\
\text { likely to influence my movie } \\
\text { going intentions }\end{array}$ & Equal variances assumed & 198 & .260 & .13997 \\
\cline { 2 - 6 } & Equal variances not assumed & 164.014 & .261 & .13997 \\
\hline
\end{tabular}


Impact Of Social Media Reviews on Cine Enthusiasts with Special Reference to Bollywood Movies

Table 18 Anova test values for mean difference between Occupation groups for effectiveness of Book my show reviews on movie going intentions

\begin{tabular}{|c|c|c|c|c|c|}
\hline \multicolumn{8}{|c|}{ ANOVA } \\
\hline \multicolumn{7}{|c|}{ Book my show reviews are likely to influence my movie going intentions } \\
\hline & Sum of Squares & df & Mean Square & F & Sig. \\
\hline Between Groups & 4.835 & 2 & 2.417 & 3.378 & .036 \\
\hline Within Groups & 140.985 & 197 & .716 & & \\
\hline Total & 145.820 & 199 & & & \\
\hline
\end{tabular}

\section{CONCLUSION}

Findings of our study indicate that demographic factors have an influence on movie preferences; this is in line with literature. The same also applies with factors influencing movie preferences. Among the demographic factors, age was found to have an influence on the effectiveness of social media reviews which included facebook and twitter. Additionally, it was found that age has got an influence on the effectiveness of IMDb and Book my show reviews. These findings give critical insights to movie makers and production houses to keep a track on user created social media content as these can influence the decisions of people in choosing whether to watch or skip a movie.

\section{REFERENCES}

[1] O'REILly, D. A. R. A. G. H., \& Kerrigan, F, Marketing the arts. In Marketing the Arts Routledge, 2010, pp. 21-24

[2] Weaver III, James B. "Exploring the links between personality and media preferences." Personality and individual differences 12.12 (1991): 1293-1299.

[3] Kraaykamp, G., \& Van Eijck, K, Personality, media preferences, and cultural participation. Personality and individual differences, 38(7), 2005, pp 1675-1688.

[4] Nabi, R. L., Finnerty, K., Domschke, T., \& Hull, S, Does misery love company? Exploring the therapeutic effects of TV viewing on regretted experiences. Journal of Communication, 56(4), 2006, pp 689-706.

[5] Sargent, S. L., Zillmann, D., \& Weaver III, J. B, The gender gap in the enjoyment of televised sports. Journal of Sport and Social Issues, 22(1), 1998, pp 46-64.

[6] Anderson, D, Love and hate in dementia: The depressive position in the film Iris. The International Journal of Psychoanalysis, 91(5), 2010, pp 1289-1297.

[7] Gantz, W., \& Wenner, L. A, Men, women, and sports: Audience experiences and effects. Journal of Broadcasting \& Electronic Media, 35(2), 1991, pp 233-243.

[8] Tamborini, R., Stiff, J., \& Heidel, C, Reacting to graphic horror: A model of empathy and emotional behavior. Communication Research, 17(5), 1990, pp 616-640.

[9] Fischoff, S, Race and sex differences in patternsof film attendance and avoidance. Paper presented at the Annual Convention of the American Psychological Association,Los Angeles, CA, 1994

[10] Oliver, M.B., Weaver, J.B., \& Sargent, S, An examinationof factors related to sex differences in enjoyment of sad films. Journal of Broadcasting and Electronic Media, 44, 2000, pp 282-30

[11] Kamhawi, R., \& Grabe, M. E, Engaging the female audience: An evolutionary psychology perspective on gendered responses to news valence frames. Journal of Broadcasting \& Electronic Media, 52(1), 2008, pp 33-51. 
[12] Janssen, E., Carpenter, D., \& Graham, C. ASelecting films for sex research: Gender differences in erotic film preference. Archives of sexual behavior, 32(3), 2003, pp 243-251.

[13] Boneva, B., Kraut, R., \& Frohlich, D, Using e-mail for personal relationships: The difference gender makes. American behavioral scientist, 45(3), 2001, pp 530-549.

[14] Roh, W., Seol, J. Y., Park, J., Lee, B., Lee, J., Kim, Y., \& Aryanfar, F, Millimeter-wave beamforming as an enabling technology for 5G cellular communications: Theoretical feasibility and prototype results. IEEE communications magazine, 52(2), 2014, pp 106-113.

[15] Mazman, S. G., \& Usluel, Y. K, Gender differences in using social networks. Turkish Online Journal of Educational Technology-TOJET, 10(2), 2011, pp 133-139.

[16] Chung, J., \& Monroe, G, Gender differences in information processing: an empirical test of the hypothesis-confirming strategy in an audit context. Accounting \& Finance, 38(2), 1998, pp 265-279. 